\title{
The Role of Parents in the Ayah's Novel by Andrea Hirata: The Study of Sociology of Literature and Its Applications in Learning Literary Appreciation in High School
}

\author{
W. Putri Yana ${ }^{1}$, Harris Effendi Thahar ${ }^{2}$ Erizal Gani $^{3}$ \\ \{windaputriyana@yahoo.com ${ }^{1}$ \} \\ ${ }^{1,2,3}$ Faculty of Language and Art, Universitas Negeri Padang, Padang, Indonesia
}

\begin{abstract}
This research is a qualitative research, which is research that is concerned with content assessment, to describe the role of parents in Ayah's novel by Andrea Hirata. Data collection techniques include the procedure of reading and understanding Andrea Hirata's Father's novel that has been provided, with the aim of gaining a clear understanding of the novel provided, recording and marking research objects found, and inventorying data related to the role of parents using table-shaped format. Data analysis techniques include the procedure of identifying data, classifying data that has been inventoried according to each problem with examples of table formats, describing data that has been classified according to their respective aspects based on the theory used in research, analyzing data, interpreting data, i.e. interpreting data results to obtain understanding in accordance with the research problem, and conclude the data obtained in the analysis of the previous stage. Based on data analysis in general, it can be concluded that there are 3 types of parental roles found in Andrea Hirata's Father's novel. in the field of education such as maturing, naming, mentoring, teaching skills, caring for and protecting children. The role of parents in the economic field such as supporting children, business development, budget planning and infrastructure procurement at home and at school. The role of parents in the social field is to invite children to work together, tolerance, respect for opinions, responsibilities, confide in and, observe the child's environment.
\end{abstract}

Keyword: Sociology of Literature

\section{Introduction}

Researchers chose Ayah's novel by Andrea Hirata as the object of research because this novel tells the figure of a father who played a role in a broken family, but the father was able to take care of children from infants to children without the assistance of a wife. In addition, parents Ayah's novel by Andrea Hirata instill norms and teach children social skills such as poetry, work and so on. Parents are also able to instill traditions and habits to children even though they have separated. In family life in general, children are born by mothers and then nurtured by both parents namely father and mother until the child can be independent. However, something else happened to the family in Ayah's novel by Andrea Hirata. In Ayah's 
novel by Andrea Hirata afther being birth by his mother the baby was under his father then under his mother care until he was at the school.

States literary sociology as a scientific and objective study of people in society, the study of religion, economics, politics and family which together form what is called the structure of sociology. [1]

Explains that the novel is a modern narrative fiction that developed in the mid-18th century. Novels take the form of prose which is longer in complexity than short stories, which express something about the quality or value of human experience. Novels are also elements of humanity that describe life events using language as its medium. So that it can penetrate the thinking power of readers and inspire readers to imagine and gain knowledge. Novels created by authors who are productive and have extensive knowledge, experience, and feelings will motivate readers to understand them intensively. Because the wisdoms expressed by the author in his novels must be a guarantee for the reader to overcome the problems of life. [2]

The role is "The dynamic aspect of the poition (status), if someone carries out rights and obligations in accordance with his position, then he performs a role". If someone has carried out an obligation or done a job, after doing the job then someone will receive rights or something that must be demanded to others. The obligation of parents towards their children is to educate and raise children, in addition, children are obliged to study diligently and be devoted to parents, because it is a right for parents.[3]

Role is a certain pattern of behavior that is characteristic of all officers of a particular job or position. Every person has a position or position, in the world of work is called an officer. Each officer has their own characteristics. One person is different from others. The difference is said to be the behavior or role it has. [4]

Parents are people who become educators and foster who are in the family environment. A parent in a family environment is an educator, teacher or teacher. It is parents who give instructions to good and bad children. Arifin also said that children are students (students) who must be educated and nurtured so that they become successful in achieving the ideals of a happy family. [5]

Literary learning in schools consists of poetry, prose (short stories and novel) appreciation activities, and drama. Novel appreciation learning has its own constraints. The constraints, as revealed, are: (1) insufficient time in school to read the novel to the end, (2) in the school there are not available various suitable novel titles as choices, and (3) almost every novel considered to be of relatively thick quality . [6]

\section{Method}

The data of this study are verbal data in the form of words or sentences, so this study is classified in qualitative research using descriptive methods. The object of this study is Andrea Hirata's Ayah novel published by Bentang 2015, (412 pages). In this study, in addition to researchers as the main tool, researchers also use stationery as other tools to mark and record research results. In this research data collection is done by: (1) reading and understanding the novel that Ayah has provided, with the aim of gaining a clear understanding of the novel provided, (2) recording and marking the research objects found, and (3) inventorying the data

\section{Result and Discussion}

a. The Role of Parents in the Field of Education 
In the novel Ayah by andrea hirata found the role of parents in the field of education. Parents educate children with the aim that children have the knowledge, experience and skills that will be used by children in the future. Education provided by parents to children starts from childhood to adulthood. The role of parents starts from maturing, naming, mentoring, teaching skills, caring for and protecting children. This can be seen in the table below.

Tabel 1. The Role of Parents in the Field of Education

The Role of Parents

No character

Soucher

Information

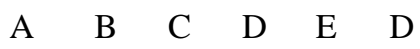

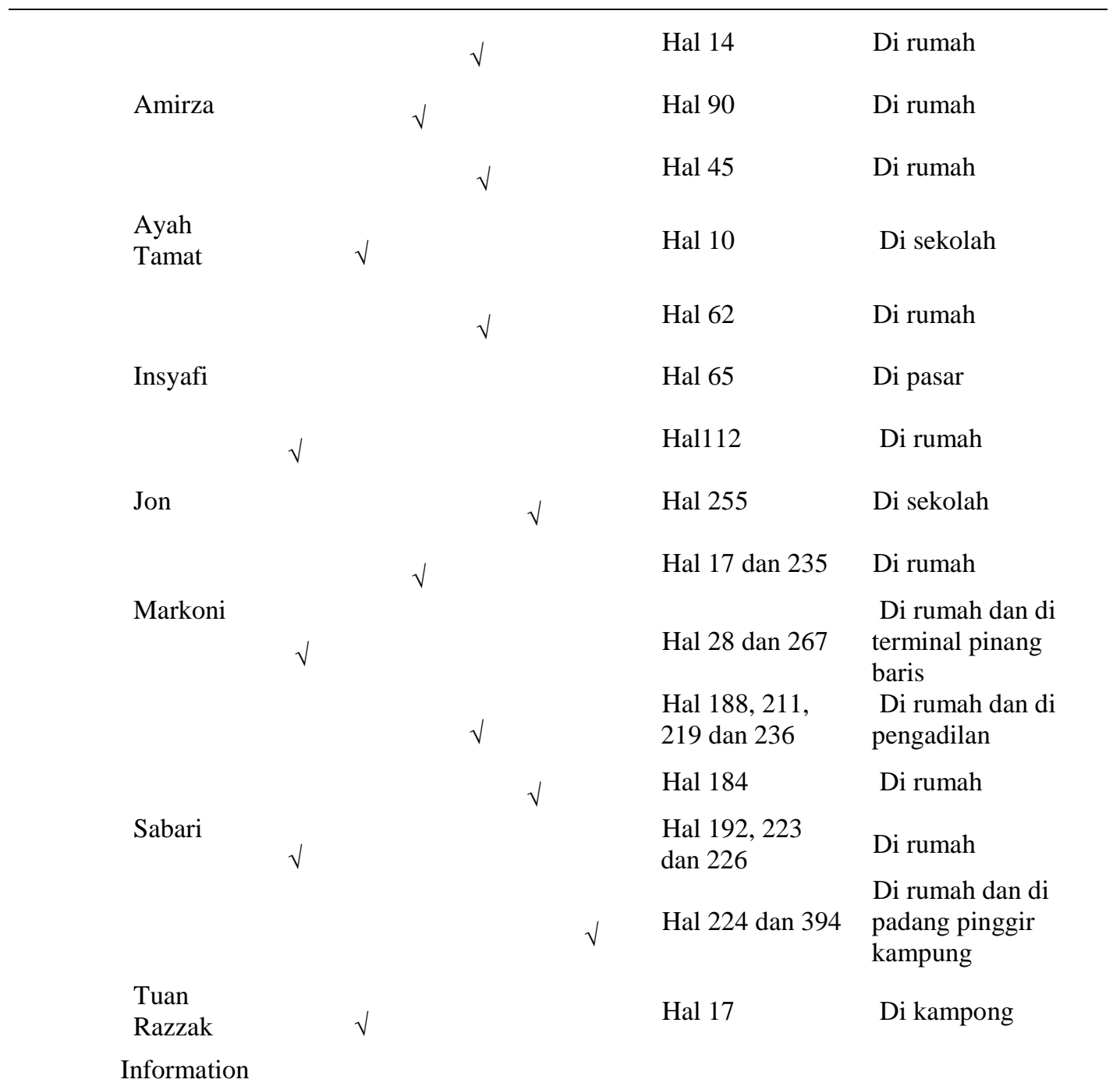



A. Pendewasaan
E. Memelihara
B. Penamaan
F. melindungi
C. Pembimbingan
D. mengajarkan

Based on the table above, it can be concluded that in Father's novel there is the role of parents in the field of education. Parents who play a role in growing a child are Amirza, Insyafi and Markoni. Parents who play a role in naming are, Tamat Father and Mr. Razak. Parents who play a role in guiding religious and cultural values are Amirza, Insyafi, Markoni and Sabari. Parents who play a role in teaching skills are Amirza, Insyafi and Sabari. Parents who play a role in caring for children are Jon and Sabari. Parents who play a role in protecting children are sabari.

\section{b. The Role of Parents in the Economy}

The role of parents in the economic field of children is very important, without parents, children may not be able to eat, buy clothes, and have a comfortable place to live. When a child is born he is unable to do anything but receive help from those around him. People who are usually around children when they are young are parents. In Andrea Hirata's Father's novel, a form of parental role in the economy is found. The role of parents in the economic field will be seen when parents support their children, business development, budget planning and procurement of facilities and infrastructure at home and at school. This can be seen in the table below.

Tabel 2. The Role of Parents in the Field of Economi

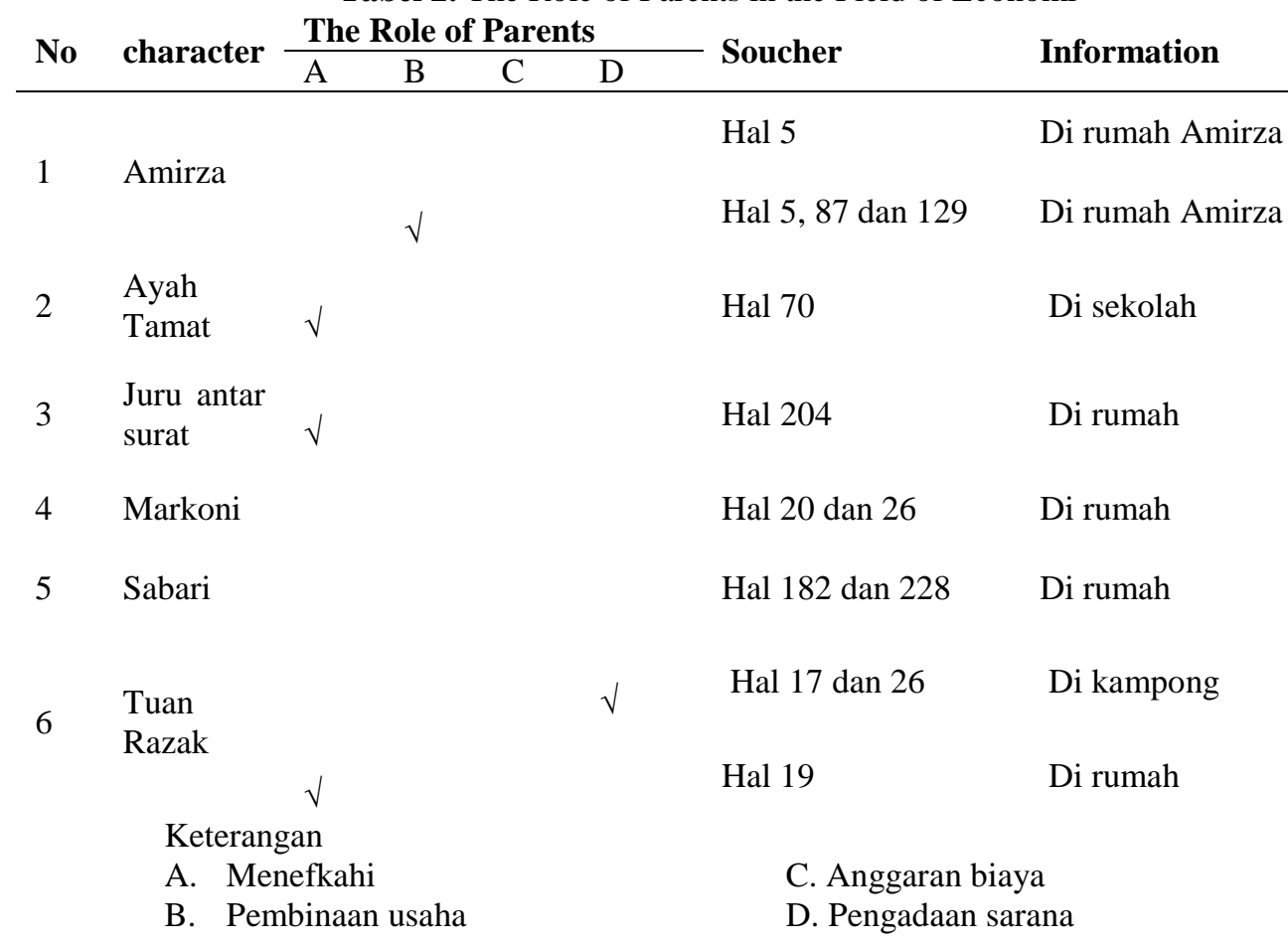


Based on the above table, it can be concluded that in Andrea Hirata's Father's novel there is the role of parents in the economic field towards children. Parents who play a role in supporting the child are the End Dad, Inter-Mail Clerk, Sabari, Mr. Razak. The parent figure who plays a role in business coaching is Amirza. Parents who play a role in the budget are Amirza and Markoni. Parents who play a role in the provision of facilities and infrastructure is Mr. Razak.

\section{c. The Role of Parents in the Social Field}

In the world of children the first social environment he knew was the family environment. The family environment is headed by parents, namely father and mother. Parents must know the social environment of children, not all social environment is good for children. Parents must be able to direct their children in a better direction by choosing a good social environment. The role of parents in the social field such as inviting children to work together, tolerance, respect for opinions, responsibilities, confide in and, observe the child's environment. this can be seen in the table below.

Tabel 3. The Role of Parents in the Field of Soscial

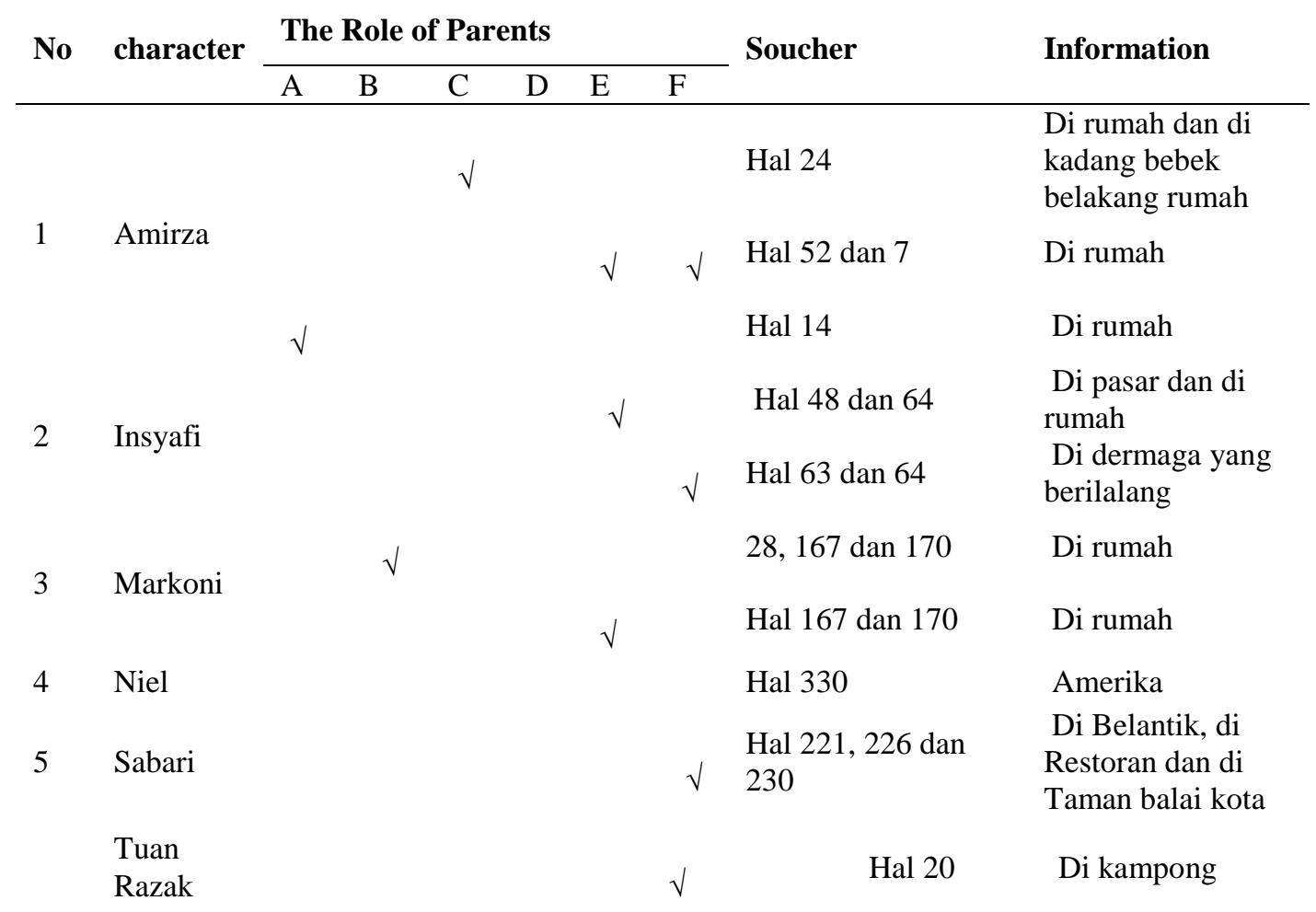

Based on the table above, it can be concluded that in Andrea Hirata's Father's novel there is the role of parents in the social field of children. A parent figure who plays a role in working with children is Amirza. The parent figure who plays a role in tolerance is Markoni. The parent figure who plays a role in respecting opinions is Amirza. Parents who have a role in 
responsibility are Amirza and Markoni. Parents who play a role in vent for children are Insyafi and Amirza. Parents who have a role in observing the environment are Amirza, Insyafi, Sabari and Mr. Razak.

\section{Conclusion}

Forms of the role of parents based on the theory used there are 3 kinds, including the role of parents in the field of education, the role of parents in the economic field and, the role of parents in the social field. The role of parents in the field of education is maturing, naming, guiding religious and cultural values, teaching skills, maintaining, and providing protection for children. The role of parents in the economic field is to provide for, business development, budget planning and, procurement of facilities and infrastructure of children at home and at school. The role of parents in the social field is cooperation, tolerance, respect for opinions, responsibility, a place to share, and care for the environment around the child

Based on data analysis, it can be concluded that the form of parental roles found in Andrea Hirata's Father's novel. The role of parents in the field of education is maturing, naming, mentoring, teaching skills, caring for and protecting children. the role of parents in maturing children is to make children mature and independent in the environment that is shown by the figures Amirza, Insyafi and Markoni.

\section{REFERENCES}

[1] Atmazaki. 2005. Ilmu Sastra: Teori dan Terapan. Padang: Angkasa Raya.

[2] Atmazaki. 2007. Dinamika Jender dalam Konteks Adat dan Agama. Padang: UNP Press.

[3] Atmazaki. 2007. Ilmu Sastra: Teori dan Terapan. Padang : UNP Press.

[4] Arifin, M. 2004. Teori-Teori Conseling Umum dan Agama. Jakarta: Golden Terayon Press.

[5] Beauvoir, Simone De. 2016. Second Sex: Fakta dan Mitos. Jakarta: PT. Buku Seru.

[6] Budianta, dkk. 2003. Membaca Sastra. Depok : Indonesiatera. Chapman Garry dan Campbell Ross. 2000. Lima Bahasa Kasih untuk Anak-Anak. Terjemahan Meitasari Tjandrasa. Batam: Interaksara

[7] Departemen Pendidikan Nasional. 2007. KBBI: Jakarta. Balai Pustaka.

[8] Endaswara, Suwardi. 2008. Metode dan Teori Pengajaran Sastra. Jakarta : Buanan Pustaka.

[9] Fathi, Bunda. 2011. Mendidik Anak dengan Al-Gur'an. Bandung: Pustaka Dasis

[10] Faruk. 2012. Pengantar Sosiologi Sastra: Dari Strukturalisme Genetik sampai. PostModernisme. Yogyakarta: Pustaka Pelajar.

[11] Fuller, Cheri. 2009. Sekolah Berawal dari Rumah. Bandung: PT. Suka Buku

[12 Hamalik, Oemar. 2007. Psikologi Belajar Mengajar. Bandung: Sinar Baru Algensindo.

[13] Hirata. Andrea. 2015. Ayah. Yogyakarta: Bentang.

[14] Soekanto, Soejono. 1997. Sosiologi Sutu Pengantar. Jakarta: Pt Rajawali Grafindo Persada. 